\title{
Article
}

\section{In Dahomey in England: A (negative) transatlantic performance heritage}

\author{
Saxon, Theresa
}

Available at http://clok.uclan.ac.uk/13030/

Saxon, Theresa ORCID: 0000-0002-2129-2570 (2015) In Dahomey in England: A (negative) transatlantic performance heritage. Atlantic Studies: Global Currents, 13 (2). pp. 265-281. ISSN 1478-8810

It is advisable to refer to the publisher's version if you intend to cite from the work. http://dx.doi.org/10.1080/14788810.2015.1113373

For more information about UCLan's research in this area go to http://www.uclan.ac.uk/researchgroups/ and search for < name of research Group>.

For information about Research generally at UCLan please go to http://www.uclan.ac.uk/research/

All outputs in CLoK are protected by Intellectual Property Rights law, including Copyright law. Copyright, IPR and Moral Rights for the works on this site are retained by the individual authors and/or other copyright owners. Terms and conditions for use of this material are defined in the policies page.

\section{CLoK}

Central Lancashire online Knowledge www.clok.uclan.ac.uk

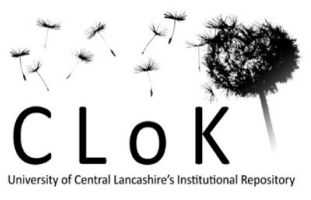


Title: In Dahomey in England: A (negative) transatlantic performance heritage

Author: Dr Theresa Saxon

Email: $\underline{\text { TSaxon@uclan.ac.uk }}$

\section{Abstract}

The first all-black American musical comedy on Broadway, In Dahomey (1902-1905), has made a name for itself in America's theatre annals and in the history of black American performance. Although critics have written about the relevance of the show in America, investigations into this turn-of-the-century performance in its wider transatlantic context have lagged behind. This article examines the reception of In Dahomey in England through specifically British interpretations of race, This article examines the reception of In Dahomey in England through specifically British interpretations of race as a negotiation of blackness, across a spectrum of racialization encoded by the pervasively prevalent minstrel/song and dance show from America and, also, the impact of African colonisation. Thus I will situate the reception of In Dahomey in London as informed by multivalent sets of racial discourses incorporating the heritage of minstrelized stagings of race and the British colonial political and cultural machinery engaged in the production and negotiation of a set of racialized imaginaries for and of Africa and the African. British audiences did not see race in the same way as American audiences but, I argue, they were as driven by racializing strategies. The transatlantic racial narrative in England produced a series of discordant images across a matrix of blackness, negotiating slippage between black American and African. But, ultimately, as Gilroy argues, the “dislocating dazzle of whiteness,” effectively sought to affirm race (white/non-white) as the ultimate marker of difference, dislodging other forms of cultural plurality in establishing an apparently unassailable racial narrative. Thus, race, as racial difference, was the primary, almost exclusive, subject of scrutiny 
in the press reviews of In Dahomey. Despite claims made in the press of a brotherhood between black performers and white audiences in England, In Dahomey was categorized by reviewers as a form of minstrelized song and dance show entangled in a racialized hierarchy. This article argues that though In Dahomey was formulated with an uplift agenda, to challenge, subtly, racial prejudice, the show's potential resistance to racialized stereotyping was, ultimately, eroded in England's auditoria.

Keywords: In Dahomey, Transatlantic, race, theatre, African American, minstrelsy, blackface, vaudeville, George Walker, Bert Williams,

The first all-black American musical comedy on Broadway, In Dahomey (premiering in 1902), has made a name for itself in America’s theatre annals and in the history of black American performance. Notable African American practitioners - actor and stage manager Jesse A. Shipp, poet Paul Lawrence Dunbar and musician Will Marion Cook - collaborated to produce this full-length musical comedy, which starred the famous and successful vaudevillian double-act of Bert Williams and George Walker as well as singer Abbie Mitchell and choreographer/dancer/singer Aida Overton Walker. Although critics have written about the relevance of the show in America, investigations into this turn-of-thecentury performance in its wider Atlantic context have lagged behind. This article examines the reception of In Dahomey in England through specifically British interpretations of race as a negotiation of blackness, across a spectrum of racialization encoded by the pervasively prevalent minstrel/song and dance show from America and, also, the impact of African colonisation. Thus I will situate the reception of In Dahomey in London as informed by multivalent sets of racial discourses incorporating the heritage of minstrelized stagings of race and the British colonial political and cultural machinery engaged in the production and negotiation of a set of racialized imaginaries for and of Africa and the African. British 
conceptualizations of race and racialization were crucial to the perpetuation of an overtly commercial and ideological colonial economy that relied on the resources of Africa differently than it had during the transatlantic slave trade and the centuries of juridical slavery. Reconstruction, such as it was, had existed as an American event, as did Jim Crow segregationary practices and legislation. In Britain and its colonies, however, racialization was practised within a particular set of substantial, albeit incoherent, coloniser fantasies, a series of discordant images that negotiated slippage between black American and African. But, ultimately, as Gilroy argues, the “dislocating dazzle of whiteness," effectively sought to affirm race (white/non-white) as the ultimate marker of difference, dislodging other forms of cultural plurality in establishing - for that time - an unassailable racial narrative. ${ }^{1}$ Thus, race, as racial difference, was the primary, almost exclusive, subject of scrutiny in the press reviews of In Dahomey. Despite claims made in the press of a brotherhood between black performers and white audiences in England, In Dahomey was stereotyped as a minstrelized song and dance show and essentialized as a black spectacle. This article argues that though In Dahomey was formulated with a form of uplift agenda to challenge, subtly, racial prejudice, the show's potential resistance to racialized stereotyping was, ultimately, eroded in England's auditoria.

In the context of American theatre history, recent criticism has explored In Dahomey from the perspective of Du Bois’ influential paradigms of double consciousness and Booker T. Washington's conceptualization of uplift - it is not the intention of this article to revisit that material, though a summary is useful in that it articulates a difficult heritage for black performers enmeshed with the history of blackface minstrelsy. As Nyong’O argues, “the grotesque blackness of the minstrel stage is as much part of [African American] history (call it 'negative heritage,' if you'd like) as the heroic legacy of Harriet Tubman.”2 As both Thomas Riis and David Krasner have discussed, the makers of In Dahomey, Jesse Shipp, 
Will Marion Cook, Paul Laurence Dunbar, Bert Williams, George Walker, Aida Walker and Abbie Mitchell, constructed their show for a black American audience in mind as well as a white. ${ }^{3}$ In American theatre history, In Dahomey is noted, therefore, for its careful calibration across what James Weldon Johnson referred to as the "two elements" crucial to the establishment of black American agency, the "radical” and “conservative,” balancing portrayals of identity positions and attitudes for a black audience with the minstrelized expectations of a white audience. ${ }^{4}$ Thomas Riis suggests that the writers and performers, as black Americans, necessarily worked “within conventions” of minstrelsy but also made available "subtle subversions of the style" for black audiences. ${ }^{5}$ Krasner also argues that in their aesthetic "striving," stars of the show Bert Williams and George Walker "unfortunately embraced the misrepresentations of white minstrelsy," but suggests that their "conventional reinscription [...] led to empowerment," inasmuch as they broke the Broadway colour-line. ${ }^{6}$ Krasner's argument here is significant: the appeal to a predominantly white American audience was a conduit for the expression of black performance arts; but in order to achieve that gain, the In Dahomey troupe were compelled to incorporate elements of the troubling minstrelized song and dance heritage.

In England that minstrel heritage was also pervasive and blackface performance had become commercially successful across legitimate/non-legitimate theatres. English stages had been enjoying Charles Mathews' blackface act in A Trip to America, since 1822, but it was, according to Lhamon, Thomas Dartmouth Rice’s portrait of “perceived blackness” that would appeal most profoundly. ${ }^{7}$ Lhamon's work focuses on white actors in blackface, locating the minstrel figure of Jim Crow as the “inaugural' symbol of 'international popular culture,” one which challenged the certainties of race as difference. ${ }^{8}$ But by the 1880 s, in England, minstrel-style song and dance shows, by white blackface and black performers had become what Baz Kershaw refers to as a "weapon of racism.”9 In Dahomey, however, in 
form and content, was a response to this heritage and was sufficiently different to what had come before in terms of black performances, to cause confusion on its opening night at the Shaftsbury Theatre. As Daphne A. Brooks argues, the show was constructed to be a “departure from conventional minstrelsy plot machinations.” ${ }^{10}$ Holly Gale Millette, also, notes the absence of minstrel conventions in the show that were, by the 1900s, expected of black performers. ${ }^{11}$ And Thomas Riis suggests that the changes made to In Dahomey in England actually drew the performers away from minstrelized dialogue and towards a “modern Afro-American kinetic style” of music and movement. ${ }^{12}$

These are significant points: that In Dahomey was structured to mark a parting from the minstrel production is made clear by composer Will Marion Cook in an interview given to The Daily News just prior to opening night in England: Cook stated that whilst he had kept it “light and amusing” in this production, “'In Dahomey’ is a foretaste of what will come” from black Americans on stage. ${ }^{13}$ The article title - “The Dawn of the New Musical - Negro Aspirations,” is significant. To Cook, In Dahomey, as a song and dance show, demonstrated the skill of black performers within a musical format that marked a break with the conventions of racialized minstrel performances and stood instead as a foreshadowing of a new form of black theatricality. Such was the aim of In Dahomey. That Cook understood the problematic heritage of minstrelsy is made clear in his reaction to an earlier production, which also featured Bert Williams and George Walker: Clorindy, or the origins of the CakeWalk, premiered in New York in 1898, and Cook claimed, following opening night, “'Gone was the uff-dah of the Minstrel! Gone the Massah Linkum stuff. We were artists and we were going a long, long, way’.”14

Cook’s attitude is clearly informed by an urge to eradicate the heritage of blackface minstrelsy, but other performers articulated amore ambivalent attitudes towards the accretion of racialization associated with the format. As Marva Griffin Carter observes, "in reality the 
‘uff-dah’ of minstrelsy was still evident in any number of Clorindy’s songs.” ${ }^{15}$ George Walker and Bert Williams articulated different assessments of their relationship with the minstrelized black performance heritage to that expressed by Cook, in terms less certain of erasure. In an oft-told tale, during the San Francisco Midwinter exhibition of 1893/94, when the boat carrying African villagers for one of the show's ethnographic Midway villages was delayed, Williams and Walker performed as Dahomians. Walker claimed subsequently: "the study of those natives interested us very much. We were not long in deciding that if we reached the point of having a show of our own we would delineate and feature native African characters as far as we could." ${ }^{16}$ Walker’s hindsight here is useful: the decision to use Dahomey as a part of the setting for the production, he recalls, stemmed from a desire on the part of himself and Bert Williams, to “delineate” African identities unfettered by minstrel tropes. But, in the same article, Walker also acknowledged that was a problem with such attempts at racial “delineation”: the minstrel show. White blackface performers, to Walker, “made themselves look as ridiculous as they could when portraying a 'darky' character. In their makeup they always had tremendously big red lips and their costumes were frightfully exaggerated." ${ }^{17}$ Walker is critical of "coloured performers" who had "imitated the white performers as 'darkies'," in a manner he considers “absurd,” but he also argues that this absurdity is a product of a racialized tradition of minstrel performance that left little room for manoeuvre. George Walker also spoke about Williams’ blackface appearances, arguing that "Mr. Williams is the first man I know of in our race to attempt to delineate a darky in a perfectly natural way, and I think much of his success is due to this fact." 18 Though arguing that Bert Williams evaded that minstrel trap, Walker’s concerns about blackface performance suggest he might not have been entirely convinced.

Bert Williams also spoke about his relationship blackface minstrelsy. In an interview he gave in 1909, he said: "I am hoping and working for the day when Negroes on the stage 
will take themselves more seriously, when the colored performer can be something more than a minstrel man, a song and dance artist, or a slap stick gent.” ${ }^{19}$ But in a later interview, in 1916, Williams’ attitude was more circumspect: “Minstrels are a thing of the past - because there are no more minstrels. To cork your face and talk politics is not minstrelsy.” ${ }^{20}$ Intriguingly, Williams added: “there are no more men like 'Daddy’ Rice, the originator of Minstrelsy.”21 Here, Williams acknowledges the cross-racial heritage of minstrelsy, which would become the subject matter of critics such as Thomas Lhamon and Eric Lott. ${ }^{22}$ Whether Williams regarded minstrelsy as a damaging heritage for black theatrical aesthetics is not brought into focus in this later interview, a factor that has exercised his biographers since. Camille Forbes recognises that ambivalence as providing a creative tension for Williams: "burnt cork became part of what enabled him to step into that onstage self, the buffer between the audience and the inner Williams.”23 But earlier biographer Ann Charters maintains that the conventions of blackface "crippled his talent and limited his achievement," thus ultimately damaging Williams’ career. ${ }^{24}$ Most hauntingly, Caryl Phillips’ novelization, Dancing in the Dark, situates Bert Williams, in blackface, at the end of a performance of In Dahomey, taking applause from the white audience; but, the narrator tells us, "his heart is heavy with shame," as he feels the futility of striving for uplift within the blackface mask of the racially conditioned comic “darky." 25

W. E. B. Du Bois, in 1924, some twenty years later, voiced his concerns about the limited landscape for black actors in America within this heritage of blackface performance, arguing that "on the stage, the negro has naturally had the most difficult chance to be recognised.” ${ }^{26}$ Du Bois acknowledges that the involvement of black performers with minstrel shows succeeded in elevating the form, but its pejoratively racializing heritage was difficult to overthrow. To Du Bois, Ira Aldridge, the most famous black American actor of the nineteenth century, "had to go to Europe for opportunity,” to avoid working only in such 
minstrelized song and dance shows. ${ }^{27}$ Europe here is regarded as a source of potential for the serious black performer, but, as I am suggesting, that potential was, in reality, very limited. Ira Aldridge himself, once T.D. Rice arrived in England from America, found it necessary to "Jump Jim Crow” in addition to performing his comic/tragic heroes. ${ }^{28}$ Du Bois is speaking retrospectively, here, and from the perspective of overt politicism associated with the development of black arts in the era immediately following the First World War, but his remarks are apposite. The racializing narratives of minstrelsy cast a long shadow in time and space and in England, at the turn of the century, the concept of blackness was very much shaped by perceptions of the song and dance performer interpolated with the new issue of African colonisation.

The attention paid to minstrelsy by black performers and writers illustrates its pervasive heritage. George Walker summarized this problem: “all that was expected of a colored performer was singing and dancing and a little story telling, but as for acting, no one credited a black person with the ability to act." ${ }^{29}$ We see this expectation in press reception for In Dahomey in England: black performers were to be the sons and daughters of the minstrel tradition, as song and dance performers, ipso facto, by virtue of being black. In the words of The Daily News, the show’s participants displayed “certain natural gifts whereof music is one. Little three-year-old darkies, when they want to say something to their mothers, often sing it.” ${ }^{30}$ The Pall Mall Gazette applauded In Dahomey for its delineation of "the coon in music, naked, unashamed, merry, pathetic, eager, and alive with emotion.”31 The review emphasises song and dance in telling tones as the black performers were coded into routines of minstrel heritage, “distinguished as local champions of cakewalking or singing.” 32 More sinisterly, the review also records, “teeth gleam, voices ring, eyes beam, and they dance with their whole bodies in an apparent ecstasy of enjoyment, alive to the finger-tips.”33 The allusion, here, to minstrel configurations of song and dance, incorporates sinister racial 
stereotyping, in descriptions of prominent "beaming” eyes and "gleaming” teeth. This review also declares that "coon songs and cake-walks are made to seem like the obvious expressions of genuine, if somewhat elementary, emotions." ${ }^{34}$ Mention of the cakewalk is significant: on the opening night, the dance was not included. But, following a clamour in the press and a flurry of demands made directly to the theatre, the cakewalk was reintroduced to the show. The English audience wanted their black performers to dance a cakewalk, and that is what they got. Reviews from 23 May onwards note that the cakewalk was back and in fact so popular that, according to The Era, the show's sponsors, Hurtig and Seamon, offered a reward to the performer "who wins the cake-walk prize most times during the week." 35 The cakewalk, as a performance type, is a product of a slippery history: a form of African tribal performance, also informed by cross-racial "parade walks," the cakewalk also operated as a satiric commentary of the social performance of white southern plantation owners. ${ }^{36}$ But, as David Krasner points out, ways in which the cakewalk was “decoded” were very much dependent on the "audience/performer relationship: who was dancing, who was observing and during what historic juncture.”37 Though a product of a "hybrid” heritage, by the turn of the century, in England, the cakewalk was “decoded” by the audience as a black dance routine, essentialized, as summed up in The Times, as a sign of "the natural expression of a racial instinct." 38

English audience fascination with the cakewalk is symptomatic of what Susan Gubar refers to as “racechange,” the "powerful attraction of black people and their culture within the white imagination.”39 That "attraction” encompasses compound perspectives, where audience fascination expresses both love/desire for the black subject (narratives of misappropriation/subjection) and fear/purgation of blackness (narratives of misappropriation/expulsion). ${ }^{40}$ But that blackness is a composition of the white imaginary and imposed upon the body of the black performer. We see this white narrative of blackness 
enacted in the reception of the cakewalk, which became encoded on British stages as "what whites thought was a black cultural form,” thus "fashioned” as an "imagined Otherness." 41 The British preoccupation with the cakewalk, then, was a desire to "expropriate black culture,” as Krasner argues, reifying blackness in a collocation of "white” narratives. ${ }^{42}$ Indeed, the concept of blackness was a key subject of In Dahomey reviews. The St James' Gazette announces that In Dahomey is “written by one gentleman of colour, composed and conducted by another, and presented upon the stage by a full company comprising mulattos, quadroons, and octoroons of both sexes and every graduation of cuticle." 43 The Times likewise records that "the chief interest of this production lies in the fact that very nearly all concerned in it are Negroes or coloured people.”44 Most tellingly, the reviewer for the Globe felt that the show wasn’t black enough:

Everything is thoroughly American and up-to-date. And that is our chief grievance against "In Dahomey”. We thought it was to be "negro” from beginning to end, and through and through - negro in its conception, its development, its characterisation, its dialogue, its music. It was to be emphatically “nigger,” with nigger thoughts and expression, nigger dialect and melody, and, above all, nigger interpretation. But is this so? What we really get is negro-America. We do not get the negro in the rough; we get him with a Yankee veneer. ${ }^{45}$

As if to ensure that the point was got, the review continued in this vein for some length: "Mr. George G. Walker, one of the two leading men, is obviously of African descent; you can see it in his features, you can see it in his voice”; the reviews further suggests, however, that Bert Williams, with his burnt-cork mask, was "a negro impersonator." ${ }^{46}$ In this review the specific signs of African blackness required to authenticate the show are not sufficiently presented. George Walker was visiblised in the review as black, exemplifying "the negro in the rough,” as an authentic delineator; however, Bert Williams’ racial indeterminacy and blackface mask 
marked him an impersonator - though considered professional in that art - a "genuine nigger minstrel," according to the London Illustrated News. ${ }^{47}$ Compellingly, according to the Sunday Sun, in wearing blackface, Williams had "made his darkness visible." ${ }^{48}$ In such analyses of Bert Williams, we see the inconsistent impact of race on British audiences. On the one hand, the racialized figure of the minstrel from America was genuine, one of authentic essential blackness, on the other, was a "veneer," a counterfeit, masking the British coloniser's construction of "the negro in the rough."

British audiences had indeed, throughout the nineteenth century, struggled with competing images of racialised blackness, and I am suggesting, these images were influenced by the concept of authentic delineation and inauthentic impersonation of blackness as a product of minstrel and vaudeville shows. ${ }^{49}$ In Britain, this audience, perhaps even more sinisterly than in America, wanted to know, control and contain black bodies, particularly striving to reconcile a constructed "Yankee veneer" with the unstable colonial imaginary of a “negro in the rough.” Even at Buckingham Palace, the King was eager to ensure that he was watching “an absolutely correct cakewalk.” 50 The production of In Dahomey provided, therefore, a staging place for transatlantic discourses on British whiteness, African blackness/es, and the "Yankee veneer.” So the British response to In Dahomey was enmeshed in an intrinsically complex matrix of racialised fantasies produced in the transatlantic imaginary in a network of discourses that were desperately seeking settlement into an exposition of racial difference, to ensure that black was drawn together to define white.

In a Foucauldian sense, the production of discourses of racialization in colonial British culture was formulated as part of a "history of the Other [...] at once interior and foreign therefore to be excluded (so as to exorcise the interior danger) but by being shut away (in order to reduce its otherness)." ${ }^{51}$ Race (as blackness) was a potential “danger” within colonial culture (the dread degenerating power/exotic lure of the "dark continent”) and was 
controlled (excluded) through containment within race discourses masquerading as knowledge. Additionally, that race knowledge was aligned with power through the assertion of a set of racial imaginaries set up between blackness and whiteness. ${ }^{52}$ From this matrix, Foucault maintains, emerges the "order of the Same”, in which each racial group, “distinguished by kinds" is “collected together into identities" - in the scenario presented here, black and white identities emerge and solidify in distinct and distinguishable camps. ${ }^{53}$ Such colonial "kinds," such collocations of blackness and whiteness, were integral to the reception of the black performers in England. As can be seen from reviews, race mattered. Though racial shades formed a major part of that discourse, what becomes clear is an urge to enforce blackness (encompassing all shades) as other to whiteness.

In England, as Sherwood argues, such a collocation of types of blackness was constructed as a reference point, creating a "myth that the British were - and are - 'white'.”54 Economically, in the late nineteenth century, Britain had become structured through colonisation and the material wealth and status of the "white" nation was predicated on a cultural economy of performative racialisation. By the turn of the century racial awareness in Britain had been refocused significantly: the "scramble for Africa" of the 1880s had made an open declaration of a form of racial politics based on the exploitation of Africans as a source of labour, and of African lands as a source of mineral wealth. And, crucially, blackness had become a product of widespread showcasing, and not just in the traditional theatrical arena: African bushmen had long been exhibited in England and in 1890, the Stanley and African exhibition at the Victoria Gallery staged Africa in a very specific set of narratives, fundamentally performative. The Times, of 22 February, 1890, situated a "built up model, nearly the size of nature, exhibiting typical village scenes" as the main attraction of the forthcoming event. ${ }^{55}$ The emphasis placed here on "scenes" is significant. As Felix Driver argues, such shows operated as “a hybrid affair, part ethnographic show part popular 
entertainment”; African identities were conscripted to perform as a set of racialised spectacle for the consumption of the coloniser audience. ${ }^{56}$ In other words, British audiences were accustomed to "shows" of blackness, from ethnological spectacle to theatrical entertainment. The fascination expressed by the press towards the racial dynamics of In Dahomey illustrates aptly that contiguity of ethnological and theatrical narratives of blackness.

British audiences had been, also, spectators of newspaper stagings of the AngloBoer War - a conflict that dominated the turn of the nineteenth into the twentieth century for imperial England. In England, the war audience, as Paula Krebs points out, were "directly dependent on newspapers" which "thrived on the daily drama of war reporting from South Africa." 57 The war on the page was fought between the white Boers of South Africa and the white imperial forces of England. The clash of white cultures, then, took centre stage in the press, overwriting, as Anne McLintock points out, "the fundamental issue of the preeminent African claim to the land and minerals." ${ }^{58}$ A few decades earlier, the Anglo-Zulu war had been staged in news stories, figuring the Zulus as villainous savages fighting heroic colonial forces, in a language of melodramatic impress. Travel writing about Africa also proliferated across the English media, for example, Henry Moreton Stanley’s Through the Dark Continent (1878) and In Darkest Africa (1890). And a memorial edition of Sir Richard Burton's A Mission to Gelele, King of Dahome (1863) was published in 1893. Charles Darwin had espoused scientific racism in The Descent of Man and Selection in Relation to Sex (1871) and his cousin Francis Galton had built on that set of paradigms in his development of eugenics. ${ }^{59}$ Other narratives widely in circulation across England produced an image of paternal affection and liberal beneficence for the aspirational African, who had committed to civilization. ${ }^{60}$ Such liberal attitudes informed much of the praise bestowed upon In Dahomey for its display of “negro” skills. The Era, for example, commented that In Dahomey was “not only played throughout by real coloured people, but written and composed by clever and able 
representatives of the Negro race." ${ }^{61}$ Reviewers managed to assert that manifesto in their descriptions of the participants as "clever negroes," and the show itself as an exemplar of “negro aspiration.” The Playgoer of July 1903 produced a souvenir edition for In Dahomey, in which it reported that the "obvious defects" of In Dahomey - the unnecessary attempt "to tell a coherent story" had prevented audiences from "seeing this clever company at its best in song and dance," but that these had been fixed, "and the show is one of the most amusing." 62

In this liberal vein, another recurrent feature of the press reviews resides in the emphasis placed on the very English welcome for the black cast and crew of In Dahomey. Little is made in reviews of deliberate racism in the audience, for example. The account in the St. James' Gazette mentions “the offensive behaviour of a negligible section of the occupants of the gallery." ${ }^{63}$ The gallery housed cheaper seats: any signs of racial violence, then, are allocated to the working class audience, the liberal bourgeois being thus exempted. To explore the pattern of that apparently liberal response to In Dahomey, a specific set of race relations that emerged around the mid-nineteenth century between black Americans and Britain, needs to be confronted. Van Gosse argues that for black Americans, Britain had been central to abolitionist debates in the era leading up to the civil war. ${ }^{64} \mathrm{~A}$ particularly British imperial agenda underpinned the Anglo partner is this informal pact, aimed at, Gosse points out, "guaranteeing England's claim to global leadership as a power both great and beneficent, a beacon of liberty versus the upstart Americans." ${ }^{65}$ For black America, the special relationship had worked on behalf of the mobilisation of abolition, establishing an international partnership to battle against slavery. Notable African American transatlantic travellers, including Harriet Jacobs, Frederick Douglass and actor Ira Aldridge, exercised what Alan Rice refers to as a "strategic Anglophilia" in this political machinery, building a body of anti-slavery support against the dominance of the white American power-base. ${ }^{66}$ 
For the producers and performers of In Dahomey, relations with the British press were similarly framed. Will Marion Cook commented, for example, “there is no feeling against us here.” ${ }^{67}$ What should be noted, though, is the supposition made by English papers that the cast and crew of In Dahomey would not encounter race prejudice in England. The reviewer for the Daily News assumed that Will Marion Cook, for example, would "know” that "in England the image in ivory recognises the image in ebony as an equal and a brother." 68 The reviewer for Mostly About People also took it as read that the "members of the In Dahomey company at the Shaftesbury Avenue Theatre are delighted with many things in this country besides their artistic success [...] they are one and all charmed beyond expression with the manner in which they and their kind are socially treated on this side of the water." 69 Such reviews are, tellingly, comparative - written to assert that England was not motivated by racial prejudice, but America was. And it would seem that, publicly at least, those involved with the show colluded with that attitude, raising no accusations of discrimination against England - though as Jeffrey Green records, there was much evidence of prejudice at play in the environs of the theatre. ${ }^{70}$ Bert Williams later recollected an incident at the performance of In Dahomey at Buckingham Palace: Jesse Shipp, without realising that he was talking to the King, had criticised some aspects of England. Williams commented, "I was grateful that the thing had happened where the monarch was a man of such great intellect [...] that we were not in Georgia, say, nor in Texas under similar circumstances.”71 Signs of overt racial intolerance were not, perhaps, so crystallized in England as in Georgia and Texas; but we can also suggest that the participants in the show demonstrated a similarly motivated "strategic Anglophilia” to that exercised by Ira Aldridge and Frederick Douglass.

However, blacks in Britain and British colonies experienced prejudice and leaders within the black community strove to foreground political agency and legitimacy 
internationally. The very first pan-African Congress took place in London in 1900, just three years prior to the staging of In Dahomey at the Shaftesbury Theatre. The event was organised by Trinidadian lawyer Henry Sylvester Williams, then resident in London. Williams had, in 1897, established the African League, with a base in London, and he had worked for black rights on an international scale, commenting on the impact of colonisation, slavery and the resultant trauma faced by Africans and subsequent generations of African diaspora. The congress was attended by W.E.B Du Bois, whose now-famous “"To the Nations of the World” address located the "color line” as an international problem - the problem of the twentieth century. Du Bois’ appeal drew attention to a crucial issue: the pan-African Congress had launched an intervention, by black political leaders globally, in the arena of African politics. Du Bois argued:

Let the Congo Free State become a great central Negro state of the world, and let its prosperity be counted not simply in cash and commerce, but in the happiness and true advancement to its black people. Let the nations of the world respect the integrity and independence of the free Negro states of Abyssinia, Liberia, Haiti, and the rest, and let the inhabitants of these states, the independent tribes of Africa, the Negroes of the West Indies and America, and the black subjects of all nations take courage, strive ceaselessly, and fight bravely, that they may prove to the world their incontestable right to be counted among the great brotherhood of mankind. ${ }^{72}$

The scale of colonial atrocities in such African “free” states aside, Du Bois' speech was a sign of overt and concerted political activism. ${ }^{73}$ But, despite the endeavours to assert an international movement on the rights of Africans and draw attention to the local contexts of Africa, the West Indies and America, 19 years passed before another pan-African congress took place. It would be contentious and erroneous to argue that racialized reception of black performances associated with the popular stage directly impeded such progress: but they may 
have had a hand in it. Certainly Frederick Douglass recognised that in England the buoyancy and enthusiasm of abolitionism in the 1840s had given way to a more sceptical attitude by the 1860s and he blamed that "pestiferous nuisance, Ethiopian minstrels: they had brought here the slang phrases, the contemptuous sneers, all originating in the spirit of Slavery.”74

The relations between American audiences, In Dahomey and the geopolitics of Africa have been explored effectively elsewhere and it is not the intention of this article to revisit those already carefully articulated debates. ${ }^{75}$ It is In Dahomey’s Africa as it was constructed and received in the English imaginary that is the subject for consideration here. According to Jeffrey Green's account of In Dahomey on London stages, the opening night led to expressions of bewilderment in the press as well as praise. Green cites the review in $S t$ James' Gazette of 18 May as an explanation: “the action of the piece is not 'In Dahomey' until the last act, and when it gets there it all goes to pieces in a manner which is little short of bewildering." ${ }^{76}$ Audiences did not realise that the show had ended, and according to the Pall Mall Gazette, “remained seated for some little while after he final fall of the curtain, unable to realize that the play was over." 77 The final act consisted of a pantomime transformation scene, in which the main characters assumed Dahomean identities, including a chorus of Caboceers. The Caboceer was a figure of some note in the British colonial economy, responsible for trading with European powers in Africa, therefore represented a form of black power in the region not entirely under colonial control. ${ }^{78}$ The Caboceers of In Dahomey are comic constructions, but the lyrics also delineate them in more sinister terms, noting, for example, their ability to "hunt” like "demons." 79 The Chorus also plays adeptly on the conclusive sign of an Africa as constructed by Stanley et al in the colonial psyche cannibalism: the king of Dahomey is named, comically, Eat-Em-All but the reference to the custom of consumption of human flesh speaks directly to what Freud would, in 1927, recognise as the ultimate taboo of "civilization.” ${ }^{80}$ Such a reference would have had an 
additional impact in the English colonial imaginary - England was, after all, trading directly in Africa and fears of the "degenerative,” demonic influence of "darkest Africa” proliferated. ${ }^{81}$ The sum of all those fears had been symbolised, notably, in Conrad's Heart of Darkness (1899), published only four years prior to the staging of In Dahomey.

But, we should remain aware, also, of the theatrical construct of Africa here. Though we have little detail about the mis en scène for the third act, stage directions indicate that it did not consist of a sinister Conradian Congo. The extant text, from the American script, describes:

A typical swamp tropical. Forms, pond lilies, and flowers of all kinds in abundance. A moonlit night. Here and therefore fireflies are seen. Small streams extending through the back of the stage to ten girls and four men dressed as frogs. Their backs, which are towards the audience, are covered with leaves etc., so that they are seen as part of the foliage of swamp till they turn to begin dance. As the curtain rises on Act III, Dance of the Frogs music softly as two lovers in idealized Frog costumes come down the stream in canoe. ${ }^{82}$

Both Brooks and Millette note the pantomimic structure of Act Three as an archetypal transformation scene familiar to audiences in England. Those audiences would have understood, also, the concept of a racialized pantomime: the famous and popular burlesque, Robinson Crusoe, had been performed regularly on the theatre circuit in London throughout the late nineteenth century, featuring, like In Dahomey, a theatrically-conceived cannibal king in a native setting. ${ }^{83}$ The show's organisers, following the opening night reviews, did move aspects of this closing transformation scene into a prologue, to ensure that the show became more obviously concluded. ${ }^{84}$ But in terms of theatrical convention this pantomimic aspect of the production was unlikely to cause significant consternation. ${ }^{85}$ 
To Brooks, the "grand tableaux" of the third act “created a brassy and colourful link between its characters and the African kingdom” and it was this intersection of body and space that disturbed audiences in London. ${ }^{86}$ Likewise, Millette argues that, in the third act, an uncanny “physiognomy of Africa” was “embodied - literally” by the transformed pantomime characters. Thus, to both Brooks and Millette, it was the juxtaposition of the African scenery and the African American body that bothered audiences, as an "ancient” Africa is transformed by the presence of the African American, once enslaved, now "uplifted." 87 In orchestrating such a theatrical intervention, interpolating non-enslaved black bodies into the African setting, suggest Brooks and Millette, the show dissented significantly from minstrelized racial typing. In this analysis, the "yankee veneer” of the African “impersonators” interrupted the coloniser fantasy of “a land of unmarked, unmoving territories" and thus destabilised the "closed” British imperial narrative of a silent, contained and conquered Africa. ${ }^{88}$

Crucially, however, as I have been arguing, the British imperial narrative of "Africa” was never absolutely "unmarked” or "unmoving” in substance or structure, or in discourse or performative act. The racial codings that incorporated Africa within the colonial psyche operating in England were fluid, enabling multiple images of racialised ethnologies, conflicting and competing, to be in circulation concurrently. The colonial imaginary was predicated on a multivalent set of narratives and, in its staging of African scenes, In Dahomey became, for English audiences, a product of Hatch’s “unparticularized” version of Africa and Africans, parts of an unstable, racialized matrix that could apply to any region of Africa, from Dahomey to Congo, and any version of colonial dialogue from bucolic to barbaric. ${ }^{89}$ Indeed, The Times emphasises the "dignity and picturesque surroundings" of the African scenery of the third act, whilst the Daily News conversely sneered that the setting indicated "a return to primitive barbarism as the ideal of the negro race." ${ }^{90}$ The narratives that fed and shaped 
colonial spectacle in the 1900s were, on the one hand, sufficiently fluid to be applied to a range of racial types, and on the other, so embedded with the mindset as to be unassailable. We should note that it was only on the opening night that In Dahomey caused any consternation with reviewers and audience. Furthermore, those first night attitudes were almost entirely positive about the show, and deemed success a likely outcome - the Daily Mail described an engaged audience, who may have "come to scoff" but "remained to laugh”; to the St James' Gazette, In Dahomey was “thoroughly attractive,” and The Times, predicted that "the show should be a great success." ${ }^{91}$ Surprise certainly featured in reviews of the opening night, and bewilderment but, overall, In Dahomey became quickly "assimilated” into the cultural economy of performative racialisation as British audiences latched onto racialised characterisations based on interpretations of the stage "negro" as an ethnologized and essentialized song and dance figure.

Audiences thus remained convinced by their own fantasy of "blackness" in the theatre arena, whether it was pleasure at the sight and sound of the "negro in the rough,” or irritation with the Yankee’s inauthentic "black” desire to "ape whiteness," or approval of a “clever negro” demonstrating an "aspirational” urge to "improve.” Such a range of perspectives are clearly visible in the reviews of In Dahomey. British audiences did not see race in the same way as American audiences, but they were as driven by racializing strategies, albeit differently conceived. There may not have been the same emphasis on hate and guilt within the British response, though desire, fascination and fear certainly informed the reception. Ultimately, for British audiences at this time, there were sufficient discursive streams of blackness that could absorb whatever version of strangeness came their way.

\footnotetext{
${ }^{1}$ Gilroy, The Black Atlantic, 9.

2 Tavia Nyong’O, “Black Theatre’s Closet Drama,” 592.
} 
${ }^{3}$ For a useful summary of the activities of the cast and crew in America on behalf of the development of black agency, particularly attitudes towards “uplift” see Krasner’s Resistance, Parody and Double Consciousness, chapters four and five.

${ }^{4}$ James Weldon Johnson, ‘Negro Americans: What Now?’ The Selected Writings of James Weldon Johnson, Volume II. Oxford: Oxford University Press, 1995. 138-179) p. 171. Also see Krasner Resistance, Parody and Double Consciousness for an exploration of the reception of In Dahomey in the context of reception and racialization in America, pp.66-73. ${ }^{5}$ Riis, Music and Scripts, xxv.

${ }^{6}$ David Krasner, Resistance, Parody, and Double Consciousness. James M. Trotter, in 1878, some 25 years prior to Du Bois, would write that the opportunity that minstrelsy provided for the Georgia Minstrels was “almost” worth the racial slurs of a "performance devoted to caricature,” Trotter, Music and some Highly Musical People, 271.

${ }^{7}$ Lhamon, Jump Jim Crow, 2

${ }^{8}$ Ibid., 4

${ }^{9}$ Kershaw. The Radical in Performance, 144

${ }^{10}$ Brooks, Bodies in Dissent, 238.

${ }^{11}$ Millette, “Strangeness and Subversion,” n.p.

${ }^{12}$ Riis, Music and Scripts, xxix.

13 “The Dawn of the New Musical - Negro Aspirations,” Daily News, 16 May 1903, 6.

${ }^{14}$ In Southern, The Music of Black Americans, 272.

${ }^{15}$ Carter, “Removing the 'Minstrel Mask,”” 208

${ }^{16}$ Walker, "The Real Coon on the American Stage," i-ii

${ }^{17}$ Ibid.

${ }^{18}$ Ibid.

${ }^{19}$ Williams, "Bert Williams in Vaudeville,” 21 
${ }^{20}$ Reprinted in Rowland ed., Bert Williams, Son of Laughter, 94.

${ }^{21}$ Ibid.

${ }^{22}$ See Lhamon, Jump Jim Crow and Lott, Love and Theft.

${ }^{23}$ Forbes, Introducing Bert Williams, 34.

${ }^{24}$ Charters, Nobody, 81.

${ }^{25}$ Philips, Dancing in the Dark, 84.

${ }^{26}$ Du Bois, Gifts of Black Folk, 146.

${ }^{27}$ Ibid.

${ }^{28}$ Lindfors, Ira Aldridge: The Vagabond Years,75.

${ }^{29}$ Walker, “The Real Coon on the American Stage,” i-ii.

30 “The Dawn of the New Musical - Negro Aspirations,” Daily News (16 May 1903): 6.

${ }^{31}$ Pall Mall Gazette (18 May 1903): 11.

${ }^{32}$ Ibid, 467.

${ }^{33}$ Ibid, 465.

${ }^{34}$ Ibid.

${ }^{35}$ The Era (20 June 1903): 12.

${ }^{36}$ Cook, "Change the Joke and Slip the Yoke: Traditions of Afro-American Satire,” 112.

${ }^{37}$ Krasner, Resistance, Parody and Double Consciousness, 81.

${ }^{38}$ The Times (18 May 1903): 12.

${ }^{39}$ Gubar, Racechanges. xviii.

${ }^{40}$ Gubar, Racechanges. See also Ralph Ellison, 'Change the Joke and Slip the Joke’: Ellison refers to minstrel as a form of "ritual exorcism" for the white audience, who can experience the thrill of desire for blackness whilst purging fears of that desire for blackness.

\footnotetext{
${ }^{41}$ Krasner, Resistance, Parody and Double Consciousness, 89

${ }^{42}$ Krasner, ibid.
} 
${ }^{43}$ St. James’s Gazette (18 May 1903) n.p.

${ }^{44}$ Both reviews appeared on 18 May 1903, 2.

45 Globe (18 May 1903) .

${ }^{46}$ Ibid.

${ }^{47}$ London Illustrated News (23 May 1902): 776.

${ }^{48}$ Sunday Sun (17 May 1903): 6.

${ }^{49}$ By the 1840s, British audiences were, Jackie Bratton maintains, troubled by 'inauthentic' minstrelsy, the general population expressed a desire to encounter 'authentic' blackness. Such a desire, argues Bratton, was a response to the racial landscape of Britain at this time, in which 'blackness' - as a material demographic presence - had become significantly diminished. See Bratton, “English Ethiopians,”128.

${ }^{50}$ The Era (27 June 1903): 10.

${ }^{51}$ Foucault, The Order of Things, xxiv.

52 The phrase “dark continent” is most closely associated with Henry Morton Stanley’s records of his journeys through Africa, titled Through the Dark Continent, published in 1878. ${ }^{53}$ Ibid.

${ }^{54}$ Sherwood “White Myths, Black Omissions,” n.p.

${ }^{55}$ The Times (22 Feb 1890): 15.

${ }^{56}$ Driver, Geography Militant, 155.

${ }^{57}$ Krebs, Gender, Race, and the Writing of Empire, 4.

${ }^{58}$ McLintock, Imperial Leather, 290.

${ }^{59}$ One of the most cited sections of Darwin’s publication states: “At some future period, not very distant as measured by centuries, the civilised races of man will almost certainly exterminate, and replace, the savage races throughout the world.” Descent of Man, 521. 
${ }^{60}$ Homi Bhabha has discussed the ambivalence of the 'mimic man,' whose status discloses "the ambivalence of colonial authority” and "disrupts its authority.” But, the "mimic men” also operate as "appropriate objects of a colonialist chain of command, authorized versions of otherness.” (Location of Culture, 126). If we refer back to Krasner’s understanding of “expropriation,” though, we see the decoding of "blackness," as a sign of Bhabha’s own sense of "not quite/not-white" (131) in the endeavour to assert the "aspirational African." ${ }^{61}$ The Era (23 May 1903): 16.

62 ““'In Dahomey’ at the Shaftesbury Theatre,” The Playgoer, 465.

6318 May 1903.

${ }^{64}$ Gosse “As a Nation, the English Are Our Friends,” 1004.

${ }^{65}$ Ibid., 1005.

${ }^{66}$ Rice, Radical Narratives, 178.

67 “The Dawn of New Music - Negro Aspirations,” The Daily News, 6. ${ }^{68}$ Ibid.

69 “Black and White,” M.A.P., 15 August 1903, n.p.

70 "the fact that there were some ninety black people staying in Central London attracted other black people to the area,” who found themselves subsequently banned from local hostelries on account of their race, though the excuses proffered by landlords focussed on 'rowdy’ behaviour (“In Dahomey in London, 38)

${ }^{71}$ Reprinted in Rowland ed., Bert Williams, Sons of Laughter, 54.

${ }^{72}$ Du Bois, “To the Nations of the World,” n.p.

${ }^{73}$ The activities of the IAC would become notorious following the publication of Roger Casement's report of the full horror of activities in Congo Free State - see Ascherson, The King Incorporated.

${ }^{74}$ Northern Daily Express, 125 
${ }^{75}$ Riis, Music and Scripts, xix. Dahomey, as a location, signified danger in America.

Dahomey, now part of Benin, had been a wealthy and, according to Thomas Riis, “aggressive “military power,” a potential symbol of “darkest part of the Dark continent.” Dahomian villages featured in several World's fairs across America in the latter decades of the nineteenth century, so there was publicity around about the nation, and its fearsome war dance and female fighting force. The very name Dahomey, then, performed as a symbol of the potentially violent primitive that was at the root of white fears of blackness.

${ }^{76}$ In Green, “In Dahomey in London,”24.

${ }^{77}$ Pall Mall Gazette (18 May 1903): 11.

${ }^{78}$ The most reliable source of “text” for In Dahomey is Riis’ Music and Scripts, but we should be wary of making too many claims based on the substance of scripting: a common feature of vaudeville comedies was flexibility, and experienced practitioners would improvise in accordance with audience response. Additionally, the only extant script for the American version does not include dialogue from the third act.

${ }^{79}$ Cook et al, “In Dahomey” in Riis, Music and Scripts, 24.

${ }^{80}$ Ibid., 26. In “An Illusion of the Future,” Freud argued that of all the "oldest instinctual wishes [of civilization],” only cannibalism had been “university proscribed” and assumed “completely surmounted,” a taboo, in short, that had been invisibilized in "civilized” society. 11.

${ }^{81}$ See Patrick Brantlinger’s Rule of Darkness: British Literature and Imperialism, 1830-1914 ${ }^{82}$ Ibid, lxvii.

${ }^{83}$ Robinson Crusoe was originally adapted by Richard Brinsley Sheridan in 1781, though there were several versions in circulation by the 1890 s.

${ }^{84}$ See Riis, Music and Scripts, lxvii, note 19; also Hatch \& Shine, 63. 
${ }^{85}$ Also, we should be aware that uncertain reviews of this third act may have been the result of the decline in popularity of pantomimes, which had been an all-year-round event, but by the early twentieth century were becoming Christmas spectacles: reviewers may have felt that the pantomime format itself was tired, and unimpressive.

${ }^{86}$ Brooks, Bodies in Dissent, 209.

${ }^{87}$ For Brooks, In Dahomey “dared to couch new images of African American identity within the old,” Bodies in Dissent 209. For Millette, the display of "repatriated bodies of the previously enslaved” in Africa, formed an African American narrative of “'uplifted” identities of the black men and women on stage,” combining to "unnerve” the British audience.

“Strangeness and Subversion,” n.p. Camille Forbes has also suggested that the representation of Africa left audiences confused (Introducing Bert Williams, 121).

${ }^{88}$ Brooks, Bodies in Dissent, 209.

${ }^{89}$ Hatch, “Some Influences on the Afro-American Theatre,” 18.

90 The Times (18 May 1903): 12; Daily News (18 May 1903): 12.

${ }^{91}$ Daily Mail (18 May 1903) 3; St. James’ Gazette, (18 May 1903): n.p.; The Times (18 May 1903):12. 
References

Addison, Gayle, Jr., Oak and Ivy: A Biography of Paul Laurence Dunbar, New York: Doubleday, 1971,

Ascherson, N. The King Incorporated: Leopold the Second and the Congo. London: Granta, 1999

Bhabha, Homi. "Of Mimicry and Man: The Ambivalence of Colonial Discourse,” Discipleship: A Special Issue on Psychoanalysis, October, Vol. 28, (Spring, 1984), pp. $125-133$

Bhabha, Homi. The Location of Culture (1994). $2^{\text {nd }}$ edition. Abingdon: Routledge Classis, 2004.

Anon, “Black and White”, M.A.P. (15 August 1903), n.p.

Anon, “Black man’s Rights”, Weekly Dispatch (13 September 1903), n.p.

Blackett, R.J.M. “Cracks in the Antislavery Wall: Frederick Douglass’s Second Visit to England (1859-1860) and the Coming of the Civil War.” Liberating Sojourn: Frederick Douglass \& Transatlantic Reform. Eds. Alan Rice \& Martin Crawford. Athens: University of Georgia Press, 1999, 187 - 206

Brantlinger, Patrick. "Victorians and Africans: The Genealogy of the Myth of the Dark Continent.” Critical Inquiry, Vol. 12, No. 1, (Autumn, 1985), 166 - 203

Bratton, J. S. “English Ethiopians: British Audiences and Black-Face Acts, 1835-1865.” The Yearbook of English Studies. Vol. 11, Literature and Its Audience, II Special Number (1981) $127-142$

Brecht, Bertolt. Brecht on Theatre: The Development of an Aesthetic, trans. John Willett (1964), $3^{\text {rd }}$ Ed. Intro by Steve Giles, and Marc Silberman, London: Methuen 2014. Brooks, Daphne. Bodies in Dissent: Spectacular Performances of Race and Freedom 18501910. Durham, NC: Duke University Press, 2006 
Carter, Marva Grifiin. “Removing the 'Minstrel Mask’ in the Musicals of Will Marion Cook.” Musical Quarterly (2000) 84 (2): 206 - 220

Charters, Ann. Nobody: The Story of Bert Williams. New York, 1970

Cook, William W., "Change the Joke and Slip the Yoke: Traditions of Afro-American Satire,” Journal of Ethnic Studies, 13: 1, 1985, 109 - 34

Anon, Daily Mail, (18 May 1903): 3

Anon, Daily Mail (19 May 1903): 3

Anon, Daily News (18 May 1903): 12

Darwin, Charles. The Descent of Man and Selection in Relation to Sex. New York: D. Appleton \& Co, 187

“Dawn of the New Musical - Negro Aspirations” Daily News (16 May 1903): 6

Driver, Felix. Geography Militant: Cultures of Exploration and Empire. London: Blackwell, 2001

Du Bois, W.E.B. “To the Nations of the World.” http://www.blackpast.org/1900-w-e-b-dubois-nations-world\#sthash.BKzO5S1K.dpuf accessed $13^{\text {th }}$ February 2015

Du Bois, W.E.B. The Souls of Black Folk: Essays and Sketches. Chicago: A. C. McClurg \& Co., 1903

Ellison, Ralph. “Change the Joke and Slip the Joke.” Shadow and Act. New York, 1964, 4559

Anon, Era (23 May 1903): 16

Anon, Era (20 June 1903): 12

Anon, Era, (27 June, 1903), 10.

Fields, Armond. Tony Pastor, Father of Vaudeville, Jefferson, N.C.: McFarland, 2007.

Forbes, Camille. Introducing Bert Williams: Burnt-cork, Broadway, and the Story of America's First Black Star, New York: Basic Civitas Books, 2008 
Foucault, Michel. The Order of Things: An Archaeology of the Human Sciences. trans. Anonymous, London: Tavistock, 1970

Freud, Sigmund. “The Future of an Illusion.” (1927). The Standard Edition of the Complete psychological works of Sigmund Freud. Trans. James Strachey, New York: W.W. Norton, 1961.

Gilroy, Paul. The Black Atlantic: Modernity and Double Consciousness. London: Verso, 1993.

Graziano, John. “In Dahomey”. Black Theatre USA. Eds. James V. Hatch and Ted Shine. New York: The Free Press, 1996, 63 - 85

Green, Jeffrey. “In Dahomey in London in 1903.” The Black Perspective in Music, Vol 11, No. 1 (Spring 1983), $22-40$

Globe (18 May 1903): n.p.

Gosse, Van. “'As a Nation, the English Are Our Friends’: The Emergence of African American Politics in the British Atlantic World, 1772-1861.” The American Historical Review, 113 no 4 (2008): 1003 - 1028

Gubar, Susan. Racechanges: White Skin, Black Face in American Culture. Oxford; Oxford University Press, 1997

Hatch, James V and Ted Shine (eds.), Black Theatre U.S.A.: The Early Period 1847-1938. Revised Edition. New York: The Free Press, 1996

Hatch, James. “Some Influences on the Afro-American Theatre,” The Theatre of Black Americans. Ed. Errol Hill, New York: Applause, 1987

Anon, “'In Dahomey’ at the Shaftesbury Theatre”, The Playgoer Vol IV, No.21 (July 1903), $465-471$

Johnson, James Weldon. 'Negro Americans: What Now?' The Selected Writings of James Weldon Johnson, Volume II. Oxford: Oxford University Press, 1995, 138 - 179 
Krasner, David. Resistance, Parody, and Double Consciousness in African American Theatre 1895-1910. New York: St. Martin’s Press, 1997

Krasner, David. “What Have We Learned?” Theatre Journal, Vol. 57, No. 4, Black Performance (December, 2005): 585 - 587

Kershaw, Baz. The Radical in Performance: Between Brecht and Baudrillard. London: Routledge, 1999

Krebs, Paula M. Gender, Race, and the Writing of Empire: Public Discourse and the Boer War. Cambridge: Cambridge University Press, 2004

Lhamon, W.T. Jump Jim Crow: Lost Play Lyrics, and Street Prose of the First Atlantic Popular Culture. Cambridge, Mass: Harvard University Press, 2002

Lindfors, Bernth. Ira Aldridge: The Vagabond Years, 1833 - 1852. Rochester, NY: University of Rochester Press.

Anon, London Illustrated News (23 May 1903): 776

Lott, Eric. Love and Theft: Blackface Minstrelsy and the American Working Class. New York: Oxford University Press, 1993

McLintock, Anne. Imperial Leather: Race, Gender, and Sexuality in the Colonial Contest. London: Routledge, 1995

Millette, Holly Gale. "Strangeness and Subversion at the Shaftesbury: In Dahomey in London in 1903.” The Victorian. Issue: 2.3 (September 2014 ): n.p.

Nyong’O, Tavia. 'Black Theatre’s Closet Drama’ Theatre Journal. Vol. 57, No. 4, Black Performance (December 2005): 590 - 592

Phillips, Caryl. Dancing in the Dark, London, Vintage Books, 2005.

Anon, Pall Mall Gazette, 18 May, 1903: 11

Rice, Alan. Radical Narratives of the Black Atlantic, London: Continuum, 2003 
Riis, Thomas. More Than Just Minstrel Shows: The Rise of Black Musical Theatre at the Turn of the Century. Brooklyn, New York: Institute for Studies in American Music, 1992

Riis, Thomas. Just Before Jazz: Black Musical Theatre in New York 1890-1915. Washington: Smithsonian Institute Press, 1989

Riis, Thomas. (ed.) The Music and Scripts of Dahomey. Madison: A-R Editions, 1996 Rowland, Mabel, ed. Bert Williams, Son of Laughter: A Symposium of Tribute to the Man and to his Work, by his Friends and Associates, New York: The English Crafters, 1925

Anon, St. James’s Gazette (18 May 1903): n.p.

Sampson, Henry T. Blacks in Blackface: A Sourcebook on Early Black Musical Shows. NJ \& London: Scarecrow Press, 1980

Sherwood, Marika. "White myths, black omissions: the historical origins of racism in Britain” International Journal of Historical Teaching, Learning and Research, Vol 3, no 1 (Jan., 2003): n.p.

https://centres.exeter.ac.uk/historyresource/journal5/Sherwood.rtf accessed 13th Feb $\underline{2015}$.

Sotiropoulos, Karen. Staging Race: Black Performers in Turn of the Century America.

Cambridge, Massachusetts: Harvard University Press, 2008

Southern, Eileen. The Music of Black Americans: A History. New York, 1971

Stanley, Henry Morton. The Congo and the Founding of its Free State. A Story of Work and Exploration, Volume 1. London: Sampson Low, Marston, Searle and Rivington, 1885 Anon, Sunday Sun, (17 May 1903): 6.

Sweeney, Fionnghuala. Frederick Douglass and the Atlantic World, Liverpool and Chicago: Liverpool University Press, 2007 
Anon, The Times (22 February 1890): 15

Anon, The Times (27 February, 1890): 5

Anon, The Times (18 May 1903): 12

Trotter, James M. Music and some Highly Musical People, Boston: Lee and Shepard 1878

Turner, (Bishop) Henry McNeal. “The American Negro and the Fatherland.” Africa and the American Negro: Addresses and Proceedings of the Congress on Africa December 13-15, 1895. Ed. John Wesley Edward Bowen, Atlanta. Gammon Theological Seminary (1896): 195 - 198

Walker, George. “The Real Coon on the American Stage.” Theatre Magazine Supplement (August 1906): i - ii.

Williams, Bert. “Bert Williams in Vaudeville.” New York Age (20 May 1909): 21

Woll, Allen, Black Musical Theatre, From Coontown to Dreamgirls. Da Capo, 1989 